\title{
The fallacy of chasing after work-life balance
}

\section{Andreas Schwingshackl * \\ Division of Critical Care Medicine, Department of Pediatrics, University of Tennessee Health Science Center, Memphis, TN, USA \\ ${ }^{*}$ Correspondence: aschwingshackl@gmail.com}

Edited and reviewed by:

Jan Hau Lee, KK Women's and Children's Hospital, Singapore

Keywords: work, life, balance, work-life balance, pediatrics, critical care, burn out

"There is no such thing as work-life balance. Everything worth fighting for unbalances your life."

$$
\text { — Alain de Botton }
$$

As a pediatric intensivist and clinicianscientist, finding a balance between work and life is essential to my professional success and my personal happiness. Failure to achieve a healthy balance will result in burn-out. So I was warned all these years since the first day of medical school. In 2013, 180 articles documented that physicians are highly dissatisfied with their jobs. This is a testament to how poorly we are balancing work and life (1-4). Interestingly, to my best knowledge, to date only 12 articles have been published specifically addressing work-life balance in Pediatrics (5-16).

Since entering medical school over two decades ago, I reached the conclusion that the concept of work-life balance acts as quicksand in our professional and personal lives resulting in slow drowning in frustration, depression, and exhaustion. The harder we fight the deeper and quicker we sink. Why are we taught to strive for work-life balance in the first place? The entire future of our modern " $24 / 7$ " society appears to revolve around mastering this concept, with the ultimate promise that - once achieved - we will all be compensated for the misery and sacrifices that we endured along the way. Astoundingly, a recent study reported an almost $20 \%$ higher job dissatisfaction rate for physicians than for the general US population (17).

In reality, the concept of work-life balance is imposed upon us by corporations, companies, and employers with the primary intent to maximize our productivity margins at the work place, not to improve our emotional or physical well-being. The cold truth is that all corporations are specifically designed to maximize their financial profit, not the happiness or well-being of their employes. For this vitally important reason, we can under no circumstances leave it to our employers to determine the quality of our own lives (18). To maintain intellectual autonomy as individuals, the task of creating our own happiness has to remain in our own hands. Some employers offer a free smartphone, a tabloid, free daycare, or other after-hour programs as part of their "benefits" package, but in reality they just provided us with the means to spend even more time at work or doing work for them.

The new buzz-word in Medicine is "flextime" $(19,20)$. Besides the fact that for some medical specialties, such as Intensive Care, flextime is a less viable concept than for other specialties, the fact still remains that if $m y$ time is flexible somebody has to work the hours that I find inconvenient. This rarely results in two happy employes. Residents and fellows are now restricted to 80 work hours per week (21) and after subtracting even as little as $6 \mathrm{~h}$ of sleep per night, they are left with $46 \mathrm{~h}$ per week to fill with "life." Therefore, medical trainees have at best half as many hours available for leisure as they are required to spend at work. Clearly, achieving a work-life balance under these conditions is extremely unlikely, probably even impossible. Importantly, despite work hour restrictions physicians' dissatisfaction with both their jobs and lives is actually at an all-time high and rising (22, 23). One can argue that residency and fellowship are only temporary occupations but in reality I do not remember working any less in medical school or now as an attending. The increased amount of responsibilities assigned to a physician once out-of-training actually accentuates rather than diminishes our daily stress level and results in further spillover of work-time into leisure-time.

As we follow our peers' instructions trying to balance work and life, the question arises: when should we achieve this balance and How do we know we achieved it? Since most of us enter the workforce as teenagers, would our high school or medical school years be a good time to start embracing this concept? Our early professional career years? At mid-career level? After retirement? While common sense tells us that the pursuit of work-life balance should occur during all stages of our careers, we all have a tendency to constantly postpone any significant improvement in our daily quality of life until after the current project is completed, after this service week, after the next promotion, after the kids are out of the house. Just how poorly we balance our work and life throughout our careers was highlighted in a recent study showing that early career physicians had the lowest satisfaction rate with their overall career choice, and mid-career physicians reported the lowest satisfaction rate with their specialty choice and their work-life balance (24). Alarmingly, similar job dissatisfaction rates have been reported for medical students and interns (25). Particularly, the high institutional demands for the new generation of clinician-scientists, which are deeply rooted in our professional culture, add further barriers to a healthy work-life balance (26). Clinicianscientists face additional challenges dealing not only with the separation between work and life but also between clinical care and research. A key reason for early career physicians to leave academic medicine is in fact the disconnection between their own priorities and those of the dominant culture of academic medicine (27). It is obvious that as physicians we are facing tremendous struggles throughout all career stages in implementing what would 
seem the natural number one priority for our health and happiness, a balanced life-style.

Personally, I concluded that the neverending chase after work-life balance actually accumulates much more frustration than satisfaction. Regardless of this depressing conclusion, we may not at all be doomed if the true payoff reveals itself not in the chase but in the achievement of work-life balance. This leads me to the second question: how would we know that we achieved it? Exactly how much life do we need to balance our work? Will we just wake up one day and feel "balanced"? Unfortunately, the absence of an objective outcome measure makes the chances of ever achieving this goal rather elusive. As the movers and shakers of our industrialized nations continue to promote the work-life balance concept as the Holy Grail of the twentyfirst century go-getter mentality, engraining into our minds that a more balanced and happier life lies just around the corner, I cannot help but getting reminded of the entrance gate at Auschwitz displaying "Arbeit Macht Frei" (Work Will Liberate You"). The pursuit of a concept that is intangible and lacks validation is unlikely to result in anything but a sense of failure and helplessness, or what most of us know as "burn-out".

Twenty-four years after entering medical school, after uncountable reminders by my peers at each step of my career that this right now is actually the best time of my life, lecture after lecture from medical school through residency and fellowship all the way to today's Faculty Development Program in my Department, I am reminded that without finding that magical worklife balance I cannot, and will not, succeed in this stressful and demanding profession $(28,29)$. Instead, over the past two decades, I realized that regardless of the number of programs our society develops to promote the concept of a healthy work-life balance it is an indisputable fact that certain career pathways, including modern academic medicine, are inherently incompatible with spending the majority of our time with our families and children, or engaging in certain hobbies such as traveling the world.

All that being said, over the past few years I have adapted a new approach to a healthier and happier life-style that resulted in much greater job satisfaction.
While the medical education system has never offered me an alternative solution to living a fulfilled life except the pursuit of work-life balance, I have come to the conclusion that as long as there is a polarity in our daily lives between what we consider work and what we consider life there will always be conflict. Only the abolition of this dichotomy will establish harmony in our lives. Once I was able to integrate rather than separate all my daily activities, harmonize rather than divide my time not only between work and life but also between clinical care and research, the pursuit of balance shifted from work-life to life-nature-universe. The result was an overwhelming daily feeling of "balance." Buddenberg-Fischer recognized in 2008 that " $a$ well-balanced integration (not separation) of professional and private life is an essential goal for the new generation of doctors" (30).

The constant pursuit of work-life balance actually worsens rather than improves our quality of life by adding additional, often unrealistic, expectations to our already stressful lives. Uncountable websites and publications promote quick fixes for the "unbalanced" health care worker (31-33). The question remains: can a successful clinician-scientist really eat six small meals a day? Work-out four times a week? Attend all family functions? Spend regular quality time with friends? The root of the problem lies in the fundamental assumption that life is good and work is bad, which is the main reason why we need a work-life balance in the first place. This distinction also implies that life only occurs whenever we are not at work, demoting the importance of work in our lives and projecting unrealistic expectations onto our time-off-work. The feeling that work is externally imposed onto us causes resentment against this activity and victimizes us as employes implying that we are forced to work against our free will. It is a fact that we spend more time at work than with our partners, our families, or in bed. Therefore, to label the majority of our time as unwanted and burdensome translates into increasing exhaustion and frustration at the workplace. This creates enormous pressure on our leisure-time to compensate for all the negative energy that accumulates at work. In return, the inability to accomplish all the regenerating goals, we had set for today results in further desperation and inevitable failure.

All humans have an intrinsic desire to create, to build, and to leave a mark and an impression, as a matter of fact to work. As humans, we have always searched the contact with other humans. We have a desire to share our experiences, creations, and achievements with others. If we consider our time at work as just that, as time with colleagues and friends that allows us to create, to build, and to leave a mark and an impression, then suddenly life has taken over work, and the pursuit of a work-life balance becomes an obsolete concept. Our happiness may in fact have nothing to do with finding balance but much rather, as John Irving writes, with finding a way of life we love and having the courage to live it.

If as physicians we stand behind the personal statements we wrote as medical students and our eloquent speeches during job interviews describing that special day we realized we were destined to become a doctor and care for sick children, then we all clearly chose this profession out of free will. If that premise holds true, then the hours spent treating sick children are part of our lives just as much as the hours sipping on a glass of wine, going on a family vacation, or fishing with our buddies. Suddenly, the border between life and work vanished, work became life, and life became work. We all have some better and some worse days, but as physicians by the end of each day we will have made a difference in at least one child's life. If at that moment, we pause for a second acknowledging this incredible achievement, recognizing that we made this world a better place for somebody today, we will experience the indescribable privilege of feeling balanced every day.

Two children died last night during my call in the ICU. One family saved the lives of four children by donating their son's organs. The other family told my team what an honor it was for them to meet us and they will never forget how we helped them cope with the tragic death of their 12-yearold daughter. I am tired, exhausted, and hungry. But right now, I am balanced.

\section{ACKNOWLEDGMENTS}

Special thanks to Dr. Sunny Anand for his never-ending support and to Dr. Jessica A. Liebman for a "feisty" but very productive discussion. 


\section{REFERENCES}

1. Rama-Maceiras P, Parente S, Kranke P. Job satisfaction, stress and burnout in anaesthesia: relevant topics for anaesthesiologists and healthcare managers? Eur J Anaesthesiol (2012) 29(7):311-9. doi:10.1097/EJA.0b013e328352816d

2. Roberts DL, Shanafelt TD, Dyrbye LN, West CP. A national comparison of burnout and work-life balance among internal medicine hospitalists and outpatient general internists. J Hosp Med (2014) 9(3):176-81. doi:10.1002/jhm.2146

3. Dyrbye LN, Sotile W, Boone S, West CP, Tan L, Satele D, et al. A survey of U.S. physicians and their partners regarding the impact of work-home conflict. J Gen Intern Med (2014) 29(1):155-61. doi:10.1007/s11606-013-2581-3

4. Embriaco N, Papazian L, Kentish-Barnes N, Pochard F, Azoulay E. Burnout syndrome among critical care healthcare workers. Curr Opin Crit Care (2007) 13(5):482-8. doi:10.1097/MCC. 0b013e3282efd28a

5. Goldacre MJ, Goldacre R, Lambert TW. Doctors who considered but did not pursue specific clinical specialties as careers: questionnaire surveys. $J R$ Soc Med (2012) 105(4):166-76. doi:10.1258/jrsm. 2012.110173

6. Takagishi J, Dabrow S. Mentorship programs for faculty development in academic general pediatric divisions. Int J Pediatr (2011) 2011:538616. doi:10.1155/2011/538616

7. Fruge E, Lakoski JM, Luban N, Lipton JM, Poplack DG, Hagey A, et al. Increasing diversity in pediatric hematology/oncology. Pediatr Blood Cancer (2011) 57(1):147-52. doi:10.1002/pbc.22977

8. Katz A, Mallory B, Gilbert JC, Bethel C, HayesJordan AA, Saito JM, et al. State of the practice for pediatric surgery - career satisfaction and concerns. A report from the American Pediatric Surgical Association Task Force on Family Issues. JPediatr Surg (2010) 45(10):1975-82. doi:10.1016/ j.jpedsurg.2010.05.011

9. Yao SQ, Tian L, Pang BD, Bai YP, Fan XY, Shen $\mathrm{FH}$, et al. Investigation on job stress of pediatricians and nurses working in pediatric department. Zhonghua Lao Dong Wei Sheng Zhi Ye Bing Za Zhi (2008) 26(9):529-32.

10. McPhillips HA, Burke AE, Sheppard K, Pallant A, Stapleton FB, Stanton B. Toward creating family-friendly work environments in pediatrics: baseline data from pediatric department chairs and pediatric program directors. Pediatrics (2007) 119(3):e596-602. doi:10.1542/peds.20062397

11. Smith NP, Dykes EH, Youngson GS, Losty PD. Is the grass greener? A survey of female pediatric surgeons in the United Kingdom. J Pediatr Surg (2006) 41(11):1879-81. doi:10.1016/j. jpedsurg.2006.06.015

12. Sectish TC, Zalneraitis EL, Carraccio C, Behrman RE. The state of pediatrics residency training: a period of transformation of graduate medical education. Pediatrics (2004) 114(3):832-41. doi:10. 1542/peds.2004-0088

13. Caniano DA, Sonnino RE, Paolo AM. Keys to career satisfaction: insights from a survey of women pediatric surgeons. J Pediatr Surg (2004) 39(6):984-90. doi:10.1016/j.jpedsurg.2004.02.039

14. Cull WL, Mulvey HJ, O’Connor KG, Sowell DR, Berkowitz CD, Britton CV. Pediatricians working part-time: past, present, and future. Pediatrics (2002) 109(6):1015-20. doi:10.1542/peds. 109.6.1015

15. Shugerman R, Linzer M, Nelson K, Douglas J, Williams R, Konrad R. Pediatric generalists and subspecialists: determinants of career satisfaction. Pediatrics (2001) 108(3):E40. doi:10.1542/peds. 108.3.e40

16. Whitelaw CM, Nash MC. Job-sharing in paediatric training in Australia: availability and trainee perceptions. Med J Aust (2001) 174(8):407-9.

17. Shanafelt TD, Boone S, Tan L, Dyrbye LN, Sotile W, Satele D, et al. Burnout and satisfaction with work-life balance among US physicians relative to the general US population. Arch Intern Med (2012) 172(18):1377-85. doi:10.1001/ archinternmed.2012.3199

18. Available at: http://www.ted.com/talks/nigel marsh_how_to_make_work_life_balance_work. 2010

19. Tucker P, Brown M, Dahlgren A, Davies G, Ebden $\mathrm{P}$, Folkard S, et al. The impact of junior doctors' worktime arrangements on their fatigue and well-being. Scand J Work Environ Health (2010) 36(6):458-65. doi:10.5271/sjweh.2985

20. Shanafelt TD, West CP, Poland GA, LaRusso NF Menaker R, Bahn RS. Principles to promote physician satisfaction and work-life balance. Minn Med (2008) 91(12):41-3.

21. Typpo KV, Tcharmtchi MH, Thomas EJ, Kelly PA, Castillo LD, Singh H. Impact of resident duty hour limits on safety in the intensive care unit: a national survey of pediatric and neonatal intensivists. Pediatr Crit Care Med (2012) 13(5):578-82. doi:10.1097/PCC.0b013e318241785c

22. Teixeira C, Ribeiro O, Fonseca AM, Carvalho AS Burnout in intensive care units - a consideration of the possible prevalence and frequency of new risk factors: a descriptive correlational multicentre study. BMC Anesthesiol (2013) 13(1):38. doi:10.1186/1471-2253-13-38

23. de Oliveira GS Jr, Chang R, Fitzgerald PC, Almeida MD, Castro-Alves LS, Ahmad S, et al. The prevalence of burnout and depression and their association with adherence to safety and practice standards: a survey of United States anesthesiology trainees. Anesth Analg (2013) 117(1):182-93. doi: 10.1213/ANE.0b013e3182917da9

24. Dyrbye LN, Varkey P, Boone SL, Satele DV, Sloan JA, Shanafelt TD. Physician satisfaction and burnout at different career stages. Mayo
Clin Proc (2013) 88(12):1358-67. doi:10.1016/j. mayocp.2013.07.016

25. Chaudhuri E, Mason NC, Newbery N, Goddard AF. Career choices of junior doctors: is the physician an endangered species? Clin Med (2013) 13(4):330-5. doi:10.7861/clinmedicine.13-4-330

26. Strong EA, De Castro R, Sambuco D, Stewart A, Ubel PA, Griffith KA, et al. Work-life balance in academic medicine: narratives of physician-researchers and their mentors. J Gen Intern Med (2013) 28(12):1596-603. doi:10.1007/ s11606-013-2521-2

27. Levine RB, Lin F, Kern DE, Wright SM, Carrese J. Stories from early-career women physicians who have left academic medicine: a qualitative study at a single institution. Acad Med (2011) 86(6):752-8. doi:10.1097/ACM.0b013e318217e83b

28. Chittenden EH, Ritchie CS. Work-life balancing: challenges and strategies. J Palliat Med (2011) 14(7):870-4. doi:10.1089/jpm.2011.0095

29. Balch CM, Shanafelt T. Combating stress and burnout in surgical practice: a review. Adv Surg (2010) 44:29-47. doi:10.1016/j.yasu.2010.05.018

30. Buddeberg-Fischer B, Stamm M, Buddeberg C, Klaghofer R. The new generation of family physicians - career motivation, life goals and worklife balance. Swiss Med Weekly (2008) 138(2122):305-12.

31. Bittner JG, Khan Z, Babu M, Hamed O. Stress, burnout, and maladaptive coping: strategies for surgeon well-being. Bull Am Coll Surg (2011) 96(8):17-22.

32. Shanafelt TD, Oreskovich MR, Dyrbye LN, Satele DV, Hanks JB, Sloan JA, et al. Avoiding burnout: the personal health habits and wellness practices of US surgeons. Ann Surg (2012) 255(4):625-33. doi:10.1097/SLA.0b013e31824b2fa0

33. Burks DJ, Kobus AM. The legacy of altruism in health care: the promotion of empathy, prosociality and humanism. Med Educ (2012) 46(3):317-25. doi:10.1111/j.1365-2923.2011.04159.x

Received: 12 March 2014; paper pending published: 14 March 2014; accepted: 16 March 2014; published online: 31 March 2014

Citation: Schwingshackl A (2014) The fallacy of chasing after work-life balance. Front. Pediatr. 2:26. doi: 10.3389/fped.2014.00026

This article was submitted to Pediatric Critical Care, a section of the journal Frontiers in Pediatrics.

Copyright (c) 2014 Schwingshackl. This is an open-access article distributed under the terms of the Creative Commons Attribution License (CC BY). The use, distribution or reproduction in other forums is permitted, provided the original author(s) or licensor are credited and that the original publication in this journal is cited, in accordance with accepted academic practice. No use, distribution or reproduction is permitted which does not comply with these terms. 